\title{
The Development of Worksheet Based on Guided Discovery Learning Method Helped by PhET Simulations Interactive Media in Newton's Laws of Motion to Improve Learning Outcomes and Interest of Vocational Education 10th Grade Students
}

\author{
Arip Nurahman ${ }^{1}$, Widodo $^{2}$, and Ishafit ${ }^{3}$, Butch O Saulon $^{4}$ \\ ${ }^{123}$ Program Studi Magister Pendidikan Fisika, Universitas Ahmad Dahlan, Yogyakarta \\ J1. Pramuka 42, Sidikan, Umbulharjo, Yogyakarta 55161. Indonesia. \\ ${ }^{4}$ Nueva Caceres University, Philippine \\ Hernandez Ave, Naga, Camarines Sur, Filipina \\ nebulaarip99@gmail.com
}

\begin{abstract}
This research was aimed to produce students worksheet (LKPD) based on PhET Interactive Simulations Software in cognitive through the application of physicsbased guided discovery learning model that is devoted to the concept of Newton's Law of Motion. Guided Discovery-based approach is expected and is believed to develop students' skills in various aspects of one study that showed achievement levels mastery of physics students after participating in the learning process under the expected educational purposes. Researchers conducted a study on the process of learning physics for the discovery-oriented at vocational senior high school students in Newton's law of motion with R\&D. Subjects were students of class X TKRO in the first semester of the academic year 2018-2019 in vocational high school in Ciamis, West Java Province as many as 35 students. Data collected through tests, observations and interviews.
\end{abstract}

Keywords: Vocational Education, Worksheet, guided discovery learning, PhET Interactive Simulations

\section{Introduction}

In the process of teaching and learning activities, and in designing learning the teacher must consider the media aspects of the learning plan. For this reason the teacher must try to use and apply learning with the help of existing media. The selection and use of media must be aligned with the learning objectives to be achieved, the characteristics of students, and the student learning environment. Learning by using PhET Simulations is one of the computing media that provides physics animations that are used as blogs. In PhET Simulations can display something material that is abstract and can be explained easily and precisely to students.

Teacher need to prepare a programmed learning facility so students reach expected mastery of learning [1]. The main role of the teacher is to help students become independent learners by presenting contextual problems, then guiding students to raise problems and facilitate investigations to solve these problems independently. One of the main goals of school activities is to increase students' ability to think critically, make rational decisions about what done or what is believed [2]. Schools should teach and empower students' thinking skills because empowering thinking skills is believed to have the potential to empower humans [3]. This phenomenon in the field is caused by the learning methods carried out by teachers tend to be dominated by certain methods, so students are passive in the learning process. The teacher only increases the cognitive knowledge of students by providing memorization of the theory of the material.

The learning method is the point of view of a teacher in looking at all the problems that exist in the learning process. This point of view is a teacher's way of thinking in addressing and resolving problems that occur in the learning process. One of the learning methods that can be used in physics subjects to enhance logical, rational, creative, and critical thinking including guided discovery learning methods, GDL is a teaching method that regulates teaching in such a way that the child obtains knowledge that he did not yet 
know was not through notification, partially or entirely found on his own. In guided discovery learning activities or learning are designed so that students can find concepts and principles through their mental processes. In finding concepts, students make observations, classify, make guesses, explain, draw conclusions and so on to find some concepts or principles [4]. Based on the background above, we are interested in conducting research on: "The Development of Worksheet Based on Guided Discovery Learning Method Helped by PhET Simulations Interactive Media in Newton's Laws of Motion to Improve Learning Outcomes and Interest of Vocational Education 10th Grade Students." In line with the description above, this study aims to find out:

Are the Worksheet's based on Guided Discovery Learning Method using the PhET Interactive Simulations Software on Newton Law of Motion fulfilling the learning media eligibility criteria?

How can a Worksheet's based on Guided Discovery Learning Method using the PhET Interactive Simulations Software on Newton Law of Motionimprove understanding of students' concepts in learning Newton's Law of motion?

\section{Literary Review}

The following are the theories that support this research:

\section{A. Discovery Learning}

The Guided Discovery Learning method is learning approach which defined as the learning process that occurs when students are not presented with lessons in their final form but are expected to organise themselves. As Bruner's opinion, that: "Discovery Learning defined as the learning that takes place when the student not presented with the subject matter in the final form, but rather is required to organise it Friction" [5] "Guided Discovery, is characterized by convergent thinking. The instructor devises a series of statements or questions that guide the learner, step by logical step, making a series of discoveries that leads to a single predetermined goal. In other words the instructor initiates a stimulus and the learner reacts by engaging in active inquiry thereby discovering the appropriate response [6].

\section{B. Newton's Law of Motion}

The subject of Physics is the main branch of science because its principles form the basis of other branches of science [9]. Newton's First Law. If the resultant of the forces acting on an object is zero (F $=0$ ), then the object: (1) An object at rest stays, and a something in motion stays in motion with the equivalent speed and the same direction unless moved upon by an unbalanced force and (2) If move in a straight, uniform manner, it will still move in a straight line. The situation mentioned above is also called the Law of Inertia.

$$
\Sigma F=0 \text { and } a=0
$$

Because objects move in translation, the Cartesian coordinate system can be written:

$$
\Sigma F_{x}=0 \text { and } \Sigma F_{y}=0 \text {. }
$$

Newton's Second Law. The acceleration caused by force acting on an object is directly proportional to that force and inversely proportional to the mass of the object.

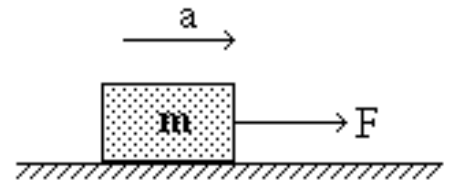

Figure 1. The acceleration caused by the force

The law of motion first summarised by Isaac Newton in his work Philosophiæ Naturalis Principia Mathematica first published on July 5, 1687. Newton used his work to explain and examine the motion of various physical and systemic objects, for example in volume three of the text, and Newton showed that by combining the laws of motion with the general law of gravity, he could explain Kepler's laws of planetary motion.

Newton's law applied to objects that are considered to be particles, in the evaluation of movement, for example, the length of the object ignored because the calculated object can be considered small, relative to the distance travelled, deformation and rotation of an object.

Table 1. Notation of Force in MKS and CGS Unit

\begin{tabular}{cccl}
\hline Value & Notation & MKS & CGS \\
\hline Force & $F$ & Newton $(\mathrm{N})$ & dyne \\
Mass & $m$ & $\mathrm{~kg}$ & $\mathrm{gram}$ \\
Acceleration & $a$ & $\mathrm{~m} / \mathrm{sec}^{2}$ & $\mathrm{~cm} / \mathrm{sec}^{2}$ \\
\hline
\end{tabular}

\section{Student Worksheet (LKPD)}

Student worksheets (LKPD) are one of the means to help and facilitate teaching and learning activities so that effective interactions between students and educators formed so that students can improve their activities in improving learning achievement [7].

Student worksheets (LKPD) are one source of learning that can be developed by educators as facilitators in learning activities. The LKPD 
prepared designed and developed under the conditions and situations of the learning activities that will be faced. Student worksheets (LKPD) are sheets containing assignments that must be done by students. Activity sheets are usually in the form of instructions, steps to complete a task. The advantage of using LKPD is to make it easier for educators to carry out learning, for students to learn independently and learn to understand and carry out a written task [8].

In the preparation of the LKPD must meet various requirements, namely didactic requirements, construction requirements and technical requirements, didactic requirements; LKPD as a form of teaching and learning process must fulfill didactic requirements, meaning that an LKPD must follow the principles of effective teaching and learning, namely: paying attention to individual differences, so that a good LKPD can be used by slow learners.

Technical requirements, from a technical point of view, have several discussions, namely: Using printed letters and not using Latin or Roman letters, using rather large bold letters, not ordinary letters that are underlined, using no more than 10 words in a row, using frames to differentiate command sentences from students' answers, try to compare the size of the letters with the size of the matching image.

D. PhET Interactive Simulations Software

Visual physics is the physics whose events can be seen with eyes include electric magnets, fluids, optics and mechanics [10]. PhET is an interactive simulation of physical phenomena, based on research provided free of charge. Researchers believe that with a research-based approach, which combines the results of previous research and what the authors do themselves allows students to connect real-life phenomena and the underlying knowledge, which can ultimately deepen understanding and increase their interest in physics. It is founded in 2002 by Nobel Physics Laureate Prof. Carl Wieman, PhD in University Colorado, USA.

Investigate the forces at work while sloping toward a cart, and pushing an icebox, stone, or student. Create an employed force and see how it makes objects move. Change friction and see how it affects the motion of objects [12].

\section{METHOD OF RESEARCH}

\section{A. Type of research}

The type of research used is Research and Development (R \& D) research with Model
Analysis-Design-Development-ImplementationEvaluation (ADDIE). Appeared in the 1990s developed by Reiser and Mollenda, one of the functions of ADDIE is to be a guideline in developing efficient and dynamic training program equipment and infrastructure and supporting the performance of the training itself.

This model was accepted because the ADDIE model is often used to describe a systematic approach to instructional development. In addition, the ADDIE model is a general learning model that is suitable for development research. This term is almost identical to the development of instructional systems. When used in the development, this process is considered sequential but also interactive, where the evaluation results of each stage can bring the development of learning to the previous stage. The final result of a stage is the initial product for the next stage. Following is the description of the five stages of the ADDIE development model: Analysis (Analisis), Design (Rancangan), Development (Pengembangan), Implementation (Implementasi), Evaluation (Evaluasi)

\section{B. Research purposes}

This study aims to produce appropriate teaching materials in the form of student worksheets based on discovery learning assisted by PhET newton law subject matter for students of SMKN 1 Rajadesa, Ciamis, West Java.

C. Place and time of research

The research was conducted at Ahmad Dahlan University in Yogyakarta and tested on class $\mathrm{X}$ Automotive Light Vehicle Engineering Department of SMK 1 Raja Desa, Ciamis, West Java. The time for media development trials is carried out in September-December 2019.

D. Respondents

The feasibility test and readability of student worksheets developed involve experts and product users, including Material experts, media experts, physics teachers, and students of SMK 1 Rajadesa, Ciamis, West Java, on the 10th grade of Automotive Light Vehicle Engineering Department in limited numbers. The subjects of this study were all students in the first semester of the Automotive Light Vehicle Engineering Department SMKN 1 Rajadesa Ciamis, West Java, the 2018/2019 school year with 35 students.

E. Data collection technique

In this development research, the data used is in the form of the results of expert trials, teachers, and the performance and knowledge of students. Data were obtained using a test instrument in the form of a rating scale questionnaire and a skill assessment sheet (psychomotor) and knowledge (cognitive) 
with the assessment rubric. The produced shown to respondents namely material experts, media experts, linguists, students and Physics teachers of class X SMKN. After examining the product, respondents then fill out the questionnaire has been given. Data obtained in the form of a questionnaire that has been filled out by the respondent.

\section{F. Research Instrument}

The instruments used in this study consist of: Analysis of needs for teachers and student, Analysis of summative test items including validity, reliability, level of difficulty, and differentiation, Evaluation questionnaire for physicists, learning media experts, and physics teachers Field trial questionnaire

G. Data analysis technique

The data obtained were investigated by calculating using a Likert scale. Likert scale is a scale used to measure attitudes, opinions, and perceptions of a person or group of people about social phenomena. The data obtained were examined using the Likert scale calculation with points 1 to 4 .

\section{Results and Discussion}

After doing the research, obtained guided discovery-based LKPD on Newton's Law material using PhET Interactive Simulations Software, then the activity to obtain a valid and practical guided discovery-based LKPD begins with passing the defining stage. Based on the products that have been designing, the results of the LKPD validation obtained according to physicists and multimedia experts. Overall results of guided discovery-based LKPD validation by the validator is $95.85 \%$. While the results of practical findings based LKPD guided by teachers and students as a whole is $90.75 \%$. The shows that discovery-based LKPD is valid and very practical.

Guided LKPD based on the Newton Law material using valid PhET Interactive Simulations software based on the results of the validator's assessment as follows:

a The material presented at the LKPD is by the competencies achieved.

b Examples of questions on LKPD are following the substance.

c The presentation of the pictures on the LKPD is bright and attractive.

d LKPD can guide students' skills to discover concepts themselves.

e LKPD in Newton's Law has a characteristic, namely LKPD developed based on guided discovery using PhET Interactive Simulations software.

Guided LKPD based on the material of Newton's Law is practically based on the results of assessments from teachers and students as follows:

a. The instructions for using LKPD can be clearly understood.

b. The presentation of the subject matter contained in LKPD is more practical and can learn repeatedly.

c. Not using a long time to fill in the LKPD because there are clear instructions.

d. The pictures on the LKPD can be clearly understood and easily understood.

In this study, two lessons conducted. 1st learning with the subject of Newton's Laws I and II. 2nd learning with the subject of Newton's Third Law. The following data obtained from the study:

Tabel 2. Recapitulations of Results of Observation of Learning Activities Conducted by Teachers

\begin{tabular}{ccc}
\hline $\begin{array}{c}\text { Learning } \\
\text { Activity }\end{array}$ & $\begin{array}{c}\text { Implementation Percentage } \\
(\%)\end{array}$ & Category \\
\hline 1 & 91,3 & Very Good \\
2 & 95,6 & Very Good \\
\hline
\end{tabular}

Based on table 2, it observed that the learning process is carried out maximally by the teacher. It is indicated by the percentage of implementation first learning $95.6 \%$ with a very good category and second learning $91.3 \%$ with a very good category. While the results of the recapitulation of student responses to the processes that occur during learning are as follows.

Table 3. Recapitulations of Observation Results of Student Response to Every Activity in Learning

\begin{tabular}{ccc}
\hline Learning & Percentage $(\%)$ & Category \\
\hline 1 & 76.2 & Good \\
2 & 80.9 & Good \\
\hline
\end{tabular}

Based on table 3, it viewed that the learning process is responded to well by students. It indicated by the percentage of student responses in the first learning $76.2 \%$ with good categories and second learning $80.9 \%$ with good categories. As many as 20 students interviewed stated that the use of LKPD in this learning was more active because they could carry out simple experiments and demonstrations on the concepts of Newton's Law I, II and III. Seven students interviewed stated that there were obstacles when conducting guided discovery-oriented learning with LKPD, 30 students after being interviewed were satisfied and pleased with the guided discovery learning method with this LKPD. A total of 21 students interviewed could answer exactly Newton's 
Nurahman et al.

Law I, 30 students answered that Newton's Second Law was $\mathrm{F}=\mathrm{m}$ a, and as many as 35 students answered that Newton's Third Law was about action-reaction.

This study are to answer the problem formulation: LKPD or worksheets based on Guided Discovery Learning physics assisted by PhET Simulations interactive media on the material of Newton's Law, testing the feasibility of physics-based LKPD Guided Discovery Learning is assisted by PhET Simulations interactive media through the validation of material experts, media experts, and users, and examines the effect of using physical LKPD on Newton's Law aided by PhET Simulations interactive media on results or learning achievement and learning interest of Grade X students of 1 Rajadesa Vocational School, Ciamis District, West Java

\section{Conclusion}

The results of the validation of the accuracy and suitability of the material on physics-guided discovery learning LKPD conducted by material experts get an interpretation of all indicators, for the two indicators assessed by material experts with 12 questions obtained an average value of $95.85 \%$. It shows that from the learning strategy and content of the substantial LKPD discovery learning guided physics has been very good and feasible used as a source of learning in physics learning. The results of guided discovery learning LKPD validation conducted by media experts get a very good interpretation on all indicators, for the two indicators assessed by two learning media experts with eight questions obtained an average value of $90.75 \%$. The shows that in terms of appearance and language, LKPD discovery learning guided physics has been very good and feasible to use as one of the learning resources in learning. For field trials, researchers are researching SMK 1 Raja Desa, Ciamis, West Java..

\section{References}

[1] C. Huda, D. Sulisworo, and M. Toifur, Analisis Buku Ajar Termodinamika dengan Konsep Technological Pedagogical and Content Knowledge (TPACK) untuk Penguatan Kompetensi Belajar Mahasiswa, Jurnal Penelitian Pembelajaran Fisika, vol. 8, no.1, 2017, pp.1-7.

[2] R H. Ennis, Critical Thinking and Subject Specificity Clarification and Needed Research. Educational Researcher, Sage Journals, vol. 18, no.3, 1989, pp. 4-10.

[3] P. R. Wikandari. Pengajaran Berpusat Kepada Siswa dan Pendekatan Konstruktivis dalam Pengajaran. UNESA. 2008.

[4] A. A. Carin, Teaching Science Through Discovery, Mcmillan Publishing Company, 1993.
The Development of Worksheet Based on Guided Discovery Learning Method Helped by PhET....

[5] J. S. Bruner, The act of discovery, Harvard Educational, vol. 31, no.1, 1961, pp. 21-32.

[6] Leutner, Detlev, (1993), Guided Discovery Learning with Computer-Based Simulation Games: Effects of Adaptive and Non-Adaptive Instructional Support, Learning and Instruction, 3 (2) p113-32.

[7] E. Widjajanti, Kualitas Lembar Kerja Siswa, Makalah Pengabdian Kepada Masyarakat. Universitas Negeri Yogyakarta, Yogyakarta, 2008.

[8] Depdiknas, Peraturan Menteri Pendidikan Republik Indonesia No. 22 Tahun 2006 Tentang Standar Isi untuk Satuan Pendidikan Dasar dan Menengah. Dirjen Dikdasmen, Jakarta, 2006.

[9] Bambang, Surahmadi, and Ishafit, Usaha Menumbuhkan Kreativitas Peserta Didik dalam Membuat Karya IPA dengan Model Pembelajaran Problem Based Instruction di SMP Negeri 1 Temanggung, Prosiding Seminar Nasional Sains dan Pendidikan Sains IX, UKSW, vol. 5, no. 1, 2014, pp. 380-385.

[10] R. Mahmudah, Y. Pramudya, D. Sulisworo, Analisis Validitas Butir Soal Certainty of Respons Index (CRI) untuk Identifikasi Miskonsepsi Materi Tata Surya dan Fenomena Astronomi. Prosiding Seminar Nasional Pendidikan Sains, pp.579-587, 2016.

[11] M. Molenda, In search of the ellusive ADDIE model, Pervormance Improvement, vol. 42, no.5, 2003, pp.34-36.

[12] Y. Ekawati, A. Haris, and B.D. Amin, Penerapan Media Simulasi Menggunakan PHET (Physics Education And Technology) Terhadap Hasil Belajar Fisika Peserta Didik Kelas X SMA Muhammadiyah Limbung. Jurnal Pendidikan Fisika, vol.3, no.1. 2015. Pp.74-82. 